\title{
Research on the Path of Integrating Red Cultural Resources into Aesthetic Education in Colleges and Universities
}

\begin{abstract}
Wenjun $\mathrm{Xu}$
Jiangxi Vocational Technical College Of Industry \& Trade, Jiangxi, Nanchang, 330038

739960103@qq.com

ABSTRACT

In the current modern education, aesthetic education, as an important method to build students' soul and improve students' quality, has played an important role in how students learn red culture. This paper mainly studies the role of aesthetic education in the educational activities of red cultural resources in Colleges and universities. Past studies have shown that aesthetic education, as an important part of all-round development education, can not only shape excellent outlook on life and values, but also cultivate and shape students' patriotism when developing red cultural resources in colleges and universities, help contemporary students better learn the red culture resources under the background of the new era, hoping to provide corresponding reference value for relevant research.
\end{abstract}

Keywords: red cultural resources; Aesthetic education in Colleges and universities; Aesthetic education; value

\section{在高校美育育人中融入红色文化资源的路径研究 徐雯君}

江西工业贸易职业技术学院 江西 南昌 330103

739960103@qq.com

摘要:

在当下现代化教育事业中, 美育作为树造学生灵魂提升学生素质的重要方法, 对于如今学生如何学习红色文 化起到了重要的作用。本文主要研究美育在高校开展红色文化资源教育活动的作用, 过去研究表明, 美育作 为全面发展教育的重要组成部分, 其本身具有塑造优异的人生观价值观的作用同时还能在高校发展红色文化 资源时培养和塑造学生的爱国主义情怀, 帮助当代学生更好学习新时代背景下的红色文化资源, 希望可以为 相关研究提供相应的参考价值。

关键词：红色文化资源；高校美育；美育育人；价值

\section{1. 红色文化资源融入高校美育育人的理论概} 况

美育作为人生当中最具重要性的教育事业之 一, 能够在本身的教育方法与教育方式基础上, 使 人们可以发展自己正确的人生观与价值观, 同时也 能更好的观察和发现世界的美。优秀的美育教育往 往能够为人们提供健康正确的审美方式，让人们能 够更好塑造美好的精神生活, 并且能够让大众认识
到爱国主义情怀的基础上加强民族自信、文化自信 的培养, 即美育是发现美, 培育美的教育。

\section{1. 以红色文化资源本体特征的视角来阐述 其融入高校美育育人的可行性}

红色资源作为我国发展社会主义先进文化的重 要基础, 也是建设民族自信精神的重要支撑。它其 中就包含了我党在峥嵘岁月中历经千辛万苦成立共 和国的奋斗史, 也有打土豪进行土地改革的革命 
史, 更有狼牙山五壮士等等的英雄史, 每一份红色 文化资源背后都体现了中国共产党员伟大的理想与 坚持不解的信念，同时继承和发展了中华民族的传 统文化与民族精神。红色资源指导了当代大学生要 坚定自己的信念, 明白自身肩上所存在的责任感与 使命感，加强投身进入建设社会，回报祖国的行列 中来。

红色资源从本身的性质上来说是具有多样性 的, 无论是物质层面, 精神层面, 文化层面还是信 息层面, 都有着相应的资源基础。对于教育工作者 而言, 在保证能够将红色资源中伟大的理想, 优秀 的先进文化, 令人刻骨铭心的革命精神以及让人难 忘的英雄人格魅力, 全都融入进当代的教育实践中 来, 坚持通过发展生动形象, 感染性极强的教育工 作, 把红色的历史变为教育课程, 真正的做到知行 合一。教育工作者也要坚持创新意识的原则, 用新 的方法去看原本的事物发展, 从而达到取其精华, 去其糟粕的学习方法。

除此之外, 红色资源在现实生活中也存在着, 非常重要的物质载体。物质载体的出现更加证实了 红色资源的多样性, 其中便包括会议旧址历史中存 留的文物, 优质的视频影像, 还有让人朗朗上口的 红色歌曲。这些都是让人能够直接的感受到红色资 源的艺术是美育的重要教育资源, 通过这些红色物 质资源能够更好的提升美育在红色文化资源教育活 动中创新发展。

\section{2. 从红色文化作为教育资源的角度来进行 阐述}

优秀的教育资源往往能够在教育活动中提升一 个人的素质与思想, 而红色文化资源就是其中之

一。美育作为我国全面发展教育的重要教育方法之 一, 其本身要做到审美实践与教育实践, 所以通过 红色文化资源对美育进行深化创新发展从红色文化 作为教育资源的角度出发可以从以下三方面得出:

一方面红色文化作为优秀的教育资源, 往往继 承发展了我国优秀的传统文化承载着时代先进精神 在那个充满血与泪的战争年代中红色资源往往证实 了先辈们的伟大理想和高尚品质往往能够带给我 们。他们不怕死, 不怕累, 只为谋求新生活的。英 雄魅力在历史的长河中, 红色之源对于中国来说是 十分重要的, 不能忘记的历史文化。

一方面作为塑造灵魂, 培育精神生活的重要手 段, 美育能够使人们更加现实的对自己的人生进行 审美观察。以人生要过得美好, 生活要过得充实没 目标就需要啊, 美育中对人们的意、知、情发展都 开发出来, 从而。通过红色文化教育资源是人们更 好的体会到物质世界, 把人追寻自由的本心, 回归 到现实生活中来, 开发自身的精神世界。
另一方面, 美育作为一种教育理念更需要的是 让学生能够在快乐中学到发现美, 看见美的能力, 而这种教育方式或者教育理念, 往往都需要在长时 间的积累中慢慢发展的, 还要通过红色教育资源中 艺术所产生的影响力去感染烘托。红色文化作品往 往都具有物质价值与精神价值的统一, 优秀的文化 资源作品, 往往能够体现一个时代的精神力量, 标 志着一个时代的精神风貌, 更加能够指导物质世界 的发展。

\section{2. 红色文化资源融入高校美育育人中的价值 体现}

红色文化资源作为我国美学精神中的文化艺术 瑰宝, 即是优秀的教育资源也是高校美育育人的重 要基础资源。在众多高校美育教育的发展中有着及 其重要的价值作用。

一是高校想要发展好美育就必须把关键放在文 化自信上来, 无论是优秀的中国传统文化, 还是中 国共产党先辈所创造的革命文化, 还是改革开放以 来具有极强的感染力与吸引力的先进时代文化都是 保持文化自信的根本, 更别说中国美学精神, 传统 美育的魅力, 以及现代社会与现代文化协调统一发 展创造的有生力量, 都为高校如何发展美育育人工 作发展新时代青年提供理念基础。

二是红色文化作为一种社会资源, 是具聚集 性, 分散性, 消耗性, 再生性, 共有性, 独占性六 个特征相互统一的深厚资源, 只有将红色文化真正 意义上的融入到高校美育育人的教育体系当中才能 够更好的培养优秀的人才, 丰富人才的创新意识, 很大程度上提高人才的综合素质, 无论是对于党和 国家的教育工作还是对于高校本身的发展而言, 都 具有极其重要的意义与价值。

三是要充分发掘红色文化资源中所存在的丰富 时代革命精神以及革命精神中所存的重要意义, 包 括先辈们的伟大理想崇高的信念, 爱国主义情怀。 这些资源往往能够为社会主义核心价值体系教育做 下深厚的基础, 并且可以有效的开展以红色文化资 源为主体, 把民族精神教育, 理想信念教育作为重 点的社会主义核心价值体系教育系统。从而使红色 资源能够在不同时代开展社会核心价值教育, 也能 发展一个时代的社会主义教育核心。

四是红色经典艺术形式中包括红色经典舞蹈、 音乐、舞台剧。其中红色经典音乐往往能够更加正 确的培养青少年的价值观人生观, 并且在红色经典 音乐的艺术氛围下, 能够有效的发展青少年属于自 己的科学价值取向。作为具有高度升华作用的情感 艺术, 红色经典音乐它本身存在着很多不同的梳理 形式, 但主要还是以很强的艺术感染力让大众在艺 
术中形成情感的共鸣, 最终得到心灵上的净化与精 神世界的震感。

\section{3. 红色文化资源融入高校美育育人的策略方 法}

艺术教育既是作为红色文化资源在高校美育育 人如何应用的重要策略, 也是美育在高校教育事业 实施过程中的主要途径。

\section{1. 要深刻认识到红色经典音乐在美育实践 中的价值}

要想把红色经典音乐真正的融入到高校美育育 人的教育事业中。就需要重点把握红色经典音乐在 大众思想意识上的重要价值, 并且把它真正意义上 的实践到美育中从而发掘其中的创新优势。一方面 要充分了解红色经典音乐的内涵, 把红色经典演员 中拥有时代特点的美育内容发掘总结出来, 另一方 面要把红色经典音乐进行完整系统的整理分类使红 色经典音乐能够具有条理化目标化的实践使用到美 育育人工作中来。就拿王颖峰学者对音乐舞蹈史诗 井冈山中群众演员的研究来说, 他有效的分析他们 在井冈山中的作用其中就有配角角色的心理变化与 审美态度的转变, 还有他们在剧中通过红色文化历 程是怎样塑造他们的三观, 从而能够更好的体现井 冈山这部音乐舞台剧史诗对于当代大学生的审美作 用。只有把红色经典音乐融入到高校每一名的教育 事业中, 才能够真正的认识到其对于美育实践的价 值。

\section{2. 要深刻认识红色音乐舞蹈在美育中的价 值}

红色音乐舞蹈在美育育人中的主要作用在于如 何使大学生能够在音乐舞蹈中学会品鉴其艺术价 值。就需要通过井冈山永远的长征等大型音乐舞蹈 剧来分析在整个音乐舞蹈剧过程中音乐舞蹈所存在 的作用与价值。在井冈山这部音乐舞蹈史诗中。可 以深刻了解到音乐作品对于整个音乐舞蹈剧来说有 着极为重要的基础作用, 它能够生动形象表现出整 个音乐舞蹈剧的感情基调。在整个音乐舞蹈剧的表 演过程中所传唱的历史革命歌曲往往是作为主线来 将不同章节的表演连接起来, 又能够通过音乐舞蹈 表现出当时红色革命的精心。所以在这部音乐舞蹈 史诗井冈山中所运用到音乐与舞蹈相结合时, 才能 够真正体现了当时红色革命文化的整个艰辛过程。 国内学者也认为音乐舞蹈对于美育教育的价值在于 如何用红色音乐舞蹈剧表现红色文化让当代青年能 够品鉴当中的艺术美, 只有这样才能够真正深刻认 识到红色音乐舞蹈对于美育的价值

\section{3. 要充分实现红色资源的育人功能}

要想充分发挥红色资源的育人功能, 就必须实 际落实好三条路径的转变。一是最大程度上的发挥 现代科技的运用用大众传媒来发挥红色资源的育人 功能。大众传媒对于当下的社会环境来说是发挥红 色资源育人能力的重要环节。只有有效的占领大众 传媒这块高地, 才能够更好的开拓红色资源育人功 能道路; 二是做好重点育人对象的三大工作, 就是 使广大新时代大学生充分能够做到红色资源进头

脑, 红色资源进课堂, 红色资源进教材的实际工 作; 三是有效地把握住时代的机会将红色资源的育 人功能最大程度上发挥出来就需要通过国家指定重 大节日以及具有红色精神的民族文化节日。来真正 让广大新时代大学生感受到红色精神的重要性, 从 而做到群体对于红色资源的感化作用。

\section{4. 要深刻理解红色文化资源的深层次价值}

深刻发掘红色文化资源, 对于高效育人的深层 次价值作用, 就必须使广大青年群体认识到红色文 化无论在如今新时代中国特色社会主义年代还是在 历史革命艰苦改革的年代发展过程中所存在的重要 意义。更要体会到红色文化中所存在的马克思主义 群众化基础, 更有着有利于于社会主义核心价值观 的发展, 以及提高国家软实力的重要作用。红色文 化承载着每个时代的革命精神, 是对于当代大学生 来说有着十分重要的教育意义。不仅能够激发当代 大学生的爱国主义思想, 还能够加强对于社会主义 核心价值体系的认识, 从而提升整体的文化素质, 只有个体的文化自信得到提升, 才能够真正意义上 提高国家层面的文化自信，保持我国的文化主权发 展。所以红色文化资源真正落实到高校美育育人的 教育事业发展中不仅仅可以使当代大学生提升获得 美品鉴美创新美的力量, 还能够提高个人素质了解 新中国成长的足迹从而诱发大学生的人生思考与启 迪，实现真正的青年文化自信。

\section{4. 结论:}

总之, 在如今新时代的教育事业发展中, 红色 文化资源是高校教育的文化基础, 学习红色文化可 以从整体上提升大学生的个人素质, 从而加强国家 整体的文化自信。只有将红色文化资源融入高校美 育人的教育工作中, 才能使高校大学生更好的认识 到红色文化资源中的文化内涵, 并且从根本意义上 加强了美育的教育理念, 当下的高校教育发展, 在 对于红色文化资源的利用上，仍旧存在着不小的挑 战，其中也包括了青年群体对于红色文化资源的不 理解与认识, 浅的存在, 美育育人能够将红色文化 资源更好的让大学生认识到其重要性, 使大学生能 
够发展自己的审美观、价值观、人生观, 希望可以 为未来美育育人教育事业提供有用的研究价值。

\section{REFERENCES}

[1] Wang Ligao. Investigation and Analysis on the tough personality of higher vocational students in ethnic minority areas under the innovative development strategy -- Taking 8 higher vocational colleges in Guangxi Zhuang Autonomous Region as an example [J]. China Vocational and technical education, 2017,0 (7): 88-92

[2] Yan Chaofei, song Binhua. On the application of red resources and its practical teaching value -- Taking the course of Ideological and moral cultivation and fundamentals of law as an example [J]. Journal of Jinggangshan University (SOCIAL SCIENCE EDITION), 2016,37 (2): 25-28

[3] Journal of social empowerment of Guizhou Normal University, Wu chunfei (2015), 114-0

[4] Wang Jingjing. Research on the ways and methods of transforming red culture into college education and teaching resources -- Taking Zunyi Normal University as the research object [J]. Journal of Zunyi Normal University, 2013,15 (2): 110-112

[5] Cai Ping, Xiao yinfen. Exploration on the artistic path of transforming red resources into educational resources -- Taking the music and dance epic Jinggangshan of red art education brand as an example [J]. Journal of Jinggangshan University (SOCIAL SCIENCE EDITION), 2011,32 (6): 22-26

[6] Xia Xuren. Adhering to the education of red resources to promote the quality development of College Students -- the exploration and practice of Shangrao Normal University in deepening moral education by using red resources $[\mathrm{J}]$. Party history and literature court, 2009 (1): 67-68

[7] $\mathrm{Wu}$ Huiling. Urgent attention to the cultivation function of red resources on College Students' core values -- a questionnaire survey and analysis of Hunan Red Resources and the cultivation of socialist core values of college students [J]. Journal of Hebei Tourism Vocational College, 2009 (4): 32-37

[8] Yang Haitao. A survey of humanistic and cultural quality education -- a re understanding of literature and art in humanistic and cultural quality education in Colleges of Finance and economics [J]. Journal of Inner Mongolia Institute of Finance and Economics (Comprehensive Edition), 2003,0 (1): 22-26
[9] Xu Gong Xian, Jia Wei Xiao. "Five development ideas": a new direction for the development of socialist literature and art -- on the development perspective of $\mathrm{Xi}$ Jinping's literary and artistic thought [J]. red culture journal, 2017,0 (2): 13-19.

[10] Hu Dadao, Yang Yun, Peng Yong. Study on the impact of red resources integrated into field survival and life education on College Students' employment concept and psychological tolerance [J]. Journal of Beijing University of physical education, 2011,34 (5): 93-96

[11] Wang Lixia. The value and Realization of red culture resources in college students' Ideological and Political Education -- Taking the red culture education in Colleges and universities in Jiangxi Province as an example [J]. Research on ideological education, 2010 (7): 54-57

[12] Peng Yong, Hu Dadao, Yang Yun. Red resources and college students' will and character education -Research on the integration of Jinggangshan red resources into college students' field survival and life education [J]. Journal of Jinggangshan University (SOCIAL SCIENCE EDITION), 2010,31 (1): 19-24

[13] Wang Zhixin. Red classic music developing continuously in Innovation -- Enlightenment from the rearrangement of the large-scale national opera "spark" [J]. Yuefu Xinsheng (Journal of Shenyang Conservatory of Music), 2016,34 (4): 148-150

[14] Yu Haojie. The necessity and urgency of educating young people on the revolutionary spirit of the Communist Party of China -- reading the tour of the revolutionary spirit of the Communist Party of China [J]. Journal of red culture, 2018,0 (3): 105-106 